\title{
An Analysis of Language Code Mixing and Code Switching Used by Teacher During English Teaching Learning Process at SMP Negeri 2 Kamang Magek
}

\author{
Andira Gea Fitria ${ }^{* *}$ and Hermawati Syarif ${ }^{2}$ \\ ${ }^{1,2}$ English Deparment, FBS Universitas Negeri Padang, Padang, Sumatera Barat 25131, Indonesia \\ *Corresponding author.Email: andiragheafitria29@gmail.com
}

\begin{abstract}
This research aims to analyze language code switching and code mixing used by teacher during English teaching learning process at SMP Negeri Kamang 2 Magek. This research focused on describing the reason of code mixing and code switching used by the teachers during English teaching learning process. Researcher interested due to the phenomenon of diversity of the language code switching and code mixing is that decide the reason of language code switching and code mixing by the teachers during English teaching learning process. In this research the researcher used the teachers' utterances to collect the data. This research is descriptive research to describe and analyze the language code switching and code mixing used by the teachers during English teaching learning process. The data of this research consist of voice recorder, observation, interview and direct note that are deemed take by a recorder during English teaching learning process start from begins until the teaching learning process ends. The subjects of this research are three English teachers. From the data collection that has been transcribed by narrow transcription and descriptive qualitative data analysis techniques is discovered that the teachers used code switching and code mixing caused by language input because of the teachers are from Minangkabau and in daily communication the teachers and the students used Bahasa Indonesia as the first language and Minangkabaunese as a native language. The finding stated that sometimes the teachers used code switching or code mixing from English into Minangkabaunese. So that it is discovered the reason of language code switching and code mixing by the teachers during English teaching learning process. The research concludes that generally teachers still do more language code switching and code mixing during English teaching learning process in the form of Indonesian and Minangkabaunese. The teachers used code switching and code mixing was not caused by weaknesses or deficiencies in speaking English and mastering English during the teaching learning process. But the teachers used code switching and code mixing because of the teacher's skills to make students understand the lesson easily. The teachers use language code switching and code mixing also to develop intimacy, to reproof and to explain the material to understanding enhancement of the students who all had pedagogical purposes.
\end{abstract}

Keywords: CODE mixing, code switching, English teaching learning process

\section{INTRODUCTION}

Languages become a part of the fundamental people need, therefore in daily activities people use language as a tool for communications. People, who are competent in processing, organizing and use language properly and correctly, can lead better and more qualified lives. By using the language, people can communicate, interact easily, express ideas, feelings, desire and so on. So that the other people will understand what are meant and what are talked about.

We will meet different people who have different languages in daily activities. It's achievable to face communication problems in different situations. When speakers of different languages interact, they can influence each other. "People will be faced to different society who have different language, it makes possible to us facing the problem of communication in different situation" [1].

In education, language is the media that teachers used to delivering subject matter during teaching learning process. Through language, students can understand what the teacher is saying. Through language as well, students can overcome the difficulties of learning. Therefore, it will be very useful if we are aware of the language used. Good language patterns can increase the efficiency and effectiveness of learning process.

English as an international language plays an important role for specific function like education, business trade, tourism, science, technology and other fields of life [2]. It is one of the factors to show the need for English learning as a foreign language or EFL in Indonesia. While English usage in Indonesia is widely found such as in movies, places, menus and 
advertisement. But in Indonesia, English not the national or second language. English is a foreign language. Different with English learners as a second language, they are usually very difficult to get exposure to natural English on daily life. Therefore in teaching English, teachers need a varied and creative process so that students can respond to ongoing learning activities.

Teacher's utterance is the principal source of EFL. That's why the input received by the students depends on what the teacher utterances. However, in reality, teachers still difficult to using English during English teaching learning process. This is because the influence of the environment is not supportive so that the Bahasa Indonesia or native language is more dominant than English during teaching learning process.

\section{Code Mixing}

Code mixing has meaning that a mixing of two or more languages and variety of languages in a single course without something in the language situation requiring the mixing of languages. Code mixing is related to the cautious mixing of two languages without any change of topic involved [3].

Using the term code mixing is interpreted when linguistic parts or language structures of two languages appear in sentences [4]. An outstanding characteristic in the code mixing is relaxing or informal situation. In formal situations, code mixing is rarely used. If any, it is due to the lack of the correct expressions in the spoken language.

There are three types of code mixing. First is intrasentential code-mixing. It happens within a phrase, a clause, or a sentence boundary [5]

\section{Example:}

ibuk tau kamu tidak mengerjakan homework at home, karajoan kini capek!

Second is intra-lexical code mixing. It happens within a word boundary.

\section{Example:}

bisa tolong ibuk ciek printkan bahan untuk ujian beko. Third, there is pronunciation changes in phonological level. The changes can be create in phonological structure. Such as, Indonesia modify into English: jan complain nilai kamu ke ibuk.

Code-mixing might occurs for some reasons. There are some reasons to code mixing. Firstly, when the item has been obtained in one language but not yet in the other language, it's can use the one device that has available to express a convinced lexical or grammatical meaning [6]. Secondly, the item temporarily unavailable, the subject is likely to resort to an equivalent form in the other language or what that thinks one. Thirdly, when the item is more complex, in one bilingual language may make use of the corresponding one from the other.

\section{Code Switching}

Code switching is as transitions or substitutions from one variant of language to another. Code switching is changes in language usage are symptomatic [7]. Code switching can represent various switching languages or dialects and mixing whether in the same conversation, the same turn or the same utterance of the same sentence [8]. Code switching used as facility for teachers and students interaction and learning so that the class management can be well-managed.

Code switching can be divided into three. First, extra sentential code switching occurs when a bilingual person insert or uses short phrase from another or different language. Such as "Baik!", "Nahh!”, “Astaga!", "Lihat!" etc. Second, inter sentential code switching it is happens when a complete sentence in a foreign language is expressed between two sentence.

\section{Example:}

"You have an assignment for the next event. Kamu harus membuat perencanaan pernikahan untuk klien kita".

Third, intra sentential code switching happens when a phrase or a clause in a foreign language is found in a sentence in the language.

Example:

"I have the problem, job yang saya ambil dibatalkan oleh client secara sepihak" [9].

There are five reason of code switching that is potentially responsible for a transition in one language code to others. The first is the speakers have code switching with a particular purpose according to the need. The second is the people with different language backgrounds with speakers can cause a code switching. The third is changes in conditions and situations are due to the appearance of a third person who assumes the function of applying the types or languages to a particular subject, to aimed correction and making more directional talks being held. The fourth is the situation changes from official to unofficial and the fifth is changing of topic conversation [10].

\section{Previous Study}

There are two previous studies in educational related to this research. Firstly, a study about English to Bahasa Indonesia Code Switching and Code Mixing [1] entitle "Code Switching and Code Mixing in Teaching Learning Process". The finding showed that there are 
four types of code switching, tag switching, inter sentential switching, intra sentential switching and intra word switching. Code mixing takes place without make different the topic and can include of different kinds levels of language such as phonology, morphology, grammatical structures or lexical items. It was also found that the teacher uses code mixing and code switching in the class in order to increase the students understanding, to transfer the knowledge to students in an appropriate method and to develop the student's ability in English as foreign language learning. Secondly, a study conducted by [11] entitled "Code Switching and Code Mixing in English Learning Process". This study indicates that, the types of code mixing might be classified into three categories namely: insertion, alternation, and congruent lexicalization.

Meanwhile in society scope also there are two previous study related that uses of code switching and code mixing. For the first a study [12] about code switching and code mixing used in the television program dialogue on the Indonesia Lawyers Club (ILC) which is an example of academics and professionals in society, entitle "An Analysis of Outer Code Switching and Code Mixing in Indonesia Lawyers Club". The finding shows that types of code switching and code mixing, those are intra sentential switching, inter sentential switching, emblematic switching, intra lexical code mixing, establishing continuity with the previous speaker, and involving a change of pronunciation.

The second is is a study of Sociolinguistics (Code: Code Switching and Code Mixing)" [13]. This study results in three types of code switching, namely tag code switching, inter sentential code switching, and intra sentential code switching. Whereas three types of code mixing are insertion words or phrases, clauses and dialects.

From previous studies above, it can be conclude that most of previous studies only focus on analyzing the types of code switching and code mixing. In this study, the researcher not only wants to find out the types of code switching and code mixing. But also, the researcher want to get further information about the reason why the teachers used them in teaching.

\section{METHOD}

Method is a way to solve the problem will be researched by describing the subject or object's situation of research (people, institution, society) based on the facts [14]. The research method is descriptive research. The purpose of descriptive qualitative research is to increase information about phenomenon in order to describe the existed condition in the field [15]. In this research, it is used to describe and analyze the language code switching and code mixing used by the teachers during English teaching learning process.

The subjects of this research are three English teachers at SMP Negeri 2 Kamang Magek, while the object was students' and teacher's interaction starting from beginning until the end of class. The instrument is the researcher herself as the main instrument. The researcher collects the data by recording the teachers' utterances during teaching process. The utterances that produced by the teachers will be recorded when they are teaching in the classroom.

The data used are observation, interview and recording method in this research. This method was used because the object of the study is the teachers' utterances. Recording is the first step in collecting the data. The researcher records the teachers' utterances. Then, the researcher transcribes the recording of the utterances to convert the data from spoken into written form. The next step is selecting. The researcher begins selecting which utterances is language code switching or code mixing. The other technique is by conducting an interview with them.

\section{RESULT AND DISSCUSSION}

There are at least three factors for code switching or code-mixing such as the language input, the linguistics development, and the general cognitive development [6]. From some descriptions of language code switching or code mixing analysis, teachers used code switching and code mixing cause of language input because of the teachers are from Minangkabau. The finding stated that sometimes the teachers' code switching or code mixing from English into Minangkabaunese. Teachers argued that they use Indonesian to code-switch or code-mix because it is used to in formal situation. Moreover the teachers used Minangkabaunese which is not a formal language during teaching learning process when the teacher angry, explained the material or giving the example in daily life.

Based on data analysis and classification the teachers' utterances, the researcher found the reasons teacher use it. The reason from the first and second teacher is to explain the material so students understand, and to introduce the new vocabularies and to make the classroom relax, so sometimes they used Bahasa Indonesia and Minangkabaunese. As long as students understand the teachers utterances, the teachers do not need to switches the language.

These are the teachers' ways to explain the lesson, so the students understand the lesson easily, know the meaning of English difficult words, phrases or sentences and feel comfortable with the lesson. The teachers also use it to develop intimacy, to reproof and to explain the 
material to understanding enhancement of the students who all had pedagogical purposes.

\section{CONCLUSION}

Based on research finding, generally teachers at SMP Negeri 2 Kamang Magek still do code switching and code mixing in the form of Indonesian and Minangkabaunese. It is not because of the weaknesses or deficiencies in speaking English and mastering English, but it helps students to understand the lesson easily.

\section{REFERENCES}

[1] Ansar, Fithrah Auliya. "Code switching and code mixing in teaching-learning process". English Education: Jurnal Tadris Bahasa Inggris, Vol. 10. 2017.

[2] Ramelan. "Introduction to linguistic analysis". IKIP Semarang Press. Semarang. 1992.

[3] Wardaugh, Ronald. "An introduction to sociolinguistics $6^{\text {th }}$ ed" . Hongkong: Graphieraft Limited. 2010.

[4] Muysken, Pieter. "A study of code mixing. bilingual speech: a typology of code-mixing”. Cambridge University Press. 2014.

[5] Luke, Joice Yulinda. "The use of code-mixing among pamonanese in parata ndaya closed-group facebook”. Jurnal Lingua Cultura Vol.9 No.1. 2015.

[6] Hoffman, C. "An introduction to bilingualism". New York: Roudledge Tailor and Francis Group. 1991.

[7] Akhtar, Huma. Khan, Asim and Fareed, Dr. Muhammad. "Code-mixing and code-switching in efl/esl context: a sociolinguistic approach". Balochistan Journal of Linguistics, Vol. 4. 2016.

[8] Fachriyah, Eva. "The function of code switching in an english language classroom”. Studies in English Language and Education Vol. 4 No 2. 2017.

[9] Mabule, Dr. D R. "What is this? is it code switching, code mixing or language alternating?". Journal of Educational and Social Research. MCSER Publishing, Rome-Italy. Vol. 5 No.1. 2015.

[10] Sutrisno, Bejo and Ariesta, Yessika. "Beyond the use of code mixing by social media influencers in instagram". Advances in Language and Literary Studies. Vol: 10 Issue: 6. 2019.

[11] Fanani, Ahmad and Ma'u Jean Antunes R.Z. “Code switching and code mixing in english learning process". Lingtera 5 (1) 2018, pp. 68-77.

[12] Dewi, Citra and Ekalaya, Yayan. "An analysis of outer code switching and code mixing in indonesia lawyers club". Literary Criticism Journal Vol. 2 No. 1. 2015
[13] Harya, Trisna Dinillah. "Sociolinguistics (code: code switching and code mixing”. Jurnal Ilmiah Kependidikan, Vol. 11. 2018.

[14] Bina M., Dani. "Deskriptif kualitatif”. 2012. http://deskriptif-kualitatif-dani-blog.htm.

[15] Bogdan and Taylor, S. "Introduction to qualitative methods: phenomenological"l. New York: A Willey Interscience Publication. 1975. 